\title{
Dialogical Odes by John Keats: Mythologically Revisited
}

\author{
Somayyeh Hashemi \\ Department of English, Tabriz Branch, Islamic Azad University, Tabriz, Iran \\ Bahram Kazemian \\ Department of English, Tabriz Branch, Islamic Azad University, Tabriz, Iran
}

\begin{abstract}
This paper, using Mikhail Bakhtin's theory of dialogism tries to investigate the indications of dialogic voice in Odes by John Keats. Indeed this study goes through the dialogic reading of 'Ode to a Nightingale', 'Ode on a Grecian Urn', 'Ode to Psyche', and 'Ode on Melancholy', considering mythological outlooks. Analyzing Keats's odes through dialogical perspective may reveal that Keats plays a role of an involved and social poet of his own time. Moreover, Keats embraces the world of fancy and imagination to free himself from sufferings of his society. Keats' odes are influenced by expression of pain-joy reality by which he builds up a dialogue with readers trying to display his own political and social engagement. Applying various kinds of mythological elements and figures within the odes may disclose Keats's historical response and reaction toward a conflicted society and human grieves in general.
\end{abstract}

Index Terms-Bakhtinian dialogism, Keats' Odes, pain, pleasure, mythology

\section{INTRODUCTION}

John Keats as one of the major poets of Romanticism, composed multiple popular poems and his odes gained the most attention of them. Going through his odes, it appears to the reader that Keats attempts to deal with different interpretation of pain and pleasure concepts. Despite the pure Romanic nature of his poems that requires them to pinpoint the most personal issues of the poet, here in his odes, his persistent challenge with ever-existing delight and sorrows of human life inspires a kind of communication with and a response from the reader. Bakhtinian dialogism as one of the theories discussing the possibility of communicative rhetoric may help justify the need for interaction with the reader in Keats's poetry.

Numerous attempts have been made to study Keats from various perspectives. Hashemi and Kazemian (2014a, b) studied dialogical nature of structure as well as theme in Keats's odes in two individual papers. This paper aims to go through mythological study of Keats's odes in the light of Bakhtinian Dialogism. Thus, primarily it will discuss the traces of Greek mythology in Keats's odes, and then it will further argue its social and political implications resulting from the main concerns of his poetry about inseparable joint of pain and pleasure of human, expressed in the odes. Finally, dialogical nature of Keats's odes indicated in a shared sense of mythology between the poet and reader will be dealt with.

\section{REVIEW OF LITERATURE}

In Bakhtin's view, observer's position has the utmost importance. Bakhtin's observer is an operative contributor in the connection with simultaneity. Considering self from dialogical perspective means that reality is not only observed but also experienced from a specific position. Thus, there is no choice, there is a must to be in dialogue both with other human beings, and with natural and cultural arrangements put together as the world. We cannot help but give the world a response. Holquist (2002) maintains that: "The world addresses us and we are alive and human to the degree that we are answerable, i.e. to the degree that we can respond to addressivity. We are responsible in the sense that we are compelled to respond" (p. 30).

In so far as human beings are organism, they cannot choose but pay attention to life. No matter how passive one appears in the eyes of others, life will not let him be inactive. Therefore, being dormant even will seem to be the activity of choosing to be passive. As a result, as Holquist (2002) mentions: "Speech had first to come into being and develop in the process of the social intercourse of organisms, so that afterward it could enter within the organism and become inner speech" (p. 143). In fact, situation of utterance and its audience determine forms of any actual utterance. In Holquist's view (2002):

Any actual utterance is an island rising from the boundless sea of inner speech; the dimensions and forms of this island are determined by the particular situation of the utterance and its audience. Situation and audience make inner speech undergo actualization into some kind of specific outer expression that is directly included into an un-verbalized 
behavioural context and in that context is amplified by actions, behaviour, or verbal responses of other participants in the utterance (p. 144).

To put in other words, the utterance is a social unit in a way that what makes up the appropriate beginnings and endings is approved by participants.

Dialogism is structured on the basis of the social, and the belief that all meaning is gained by struggle. In Holquist's (2002) view since in dialogism always more than one meaning exists, it necessitates to be aphilosophy of language. For Bakhtin, the only way to understand and explain the world is by minimizing the number of its meanings to a limited set. Here, language seems as a place in which dialogical relationships are perceived; it displays itself in discourse which is the world centred towards another. Dentith (1995) introduces social languages and states that:

Bakhtin does not draw substantially upon the category of ideology but instead insists upon the multiplicity of social languages that make up the apparent unity of a national language; any utterance therefore takes place between language users who are socially marked in the very language they use (p. 50).

Dialogism discusses that we comprehend existence by defining our particular place in it within time and space. Dialogically believed, the present is a dynamic moment, a combination of past and present relations. Indeed, there is neither a first word nor a last one and the contexts of dialogue are infinite. Holquist (2002) argues that dialogues go through the deepest past and the most far-fetched future:

Even meanings born in dialogues of the remotest past will never be finally grasped once and for all, for they will always be renewed in later dialogue. At any present moment of the dialogue there are great masses of forgotten meanings, but these will be recalled again at a given moment in the dialogue's later course when it will be given new life. For nothing is absolutely dead: every meaning will someday have its homecoming festival. (p. 39)

A good deal has been written about differences between heroes in Greek texts and heroes as they appear in later works. An important distinction is a kind of increase in self-consciousness that earlier heroes used to lack. In fact, ancient heroes' lives unfolded in public since they were so externalized. Nonetheless, the pattern of public space that forms Romantic literary texts has some aspects in common with the chronotope of public spaces in $5^{\text {th }}$.B.C Athens. Holquist (2002) also adds that:

In such a chronotope nothing was intimate, or private, secret or personal, anything relating solely to the individual himself, anything that was, in principle, solitary... [Therefore] the individual is open on all sides, he is all surface, there is in him nothing that exists "for his sake alone," nothing that could not be subject to public or state control and evaluation. Everything here, down to the last detail, is public (p. 125).

Bakhtin also comes up with a series of different literary forms, beginning again with the Greek romances, trying to show how they are organized around interconnected ideas of time and space. "Thus in his account of the adventure time-the manner of conceiving the time in which the adventures happen-of the Greek romance, time is empty, outside biographical, social or natural significance; it is a hiatus in which adventures occur"(Dentith, 1995, p. 76).

A literary genre by its nature is reflective of the most stable inclinations in literature's development. It can introduce special aspects of conflict in life and career of ancient time and develop them without any changes from mythic forms. Moreover, immortal elements of the archaic are maintained in a genre. Due to their persistent renewal, these archaic elements are kept as authentic. Thus, Bakhtin maintains that: "a genre is always the same and yet not the same, always old and new simultaneously" (Holquist, 2002, p. 126). Holquist (2002) later argues that:

The encomium's emphasis on generalized careers, for example, is a structural inheritance from the past of ancient myth: it translates into stories about humans a pattern already present in older tales about demi-gods. In those, too, names signified certain well-known career narratives rather than individuals with unique lives (p. 127).

Since it is assumed that language is never related to or existed in a single unit, literary language is itself capable of being stratified and heteroglot; e.g. stratification into genres. Furthermore, social classes and stratifications can utilize and also change language. Thus, in Holquist' (1981) view, language at any given moment of its historical being is heteroglot:

It represents the coexistence of socio-ideological contradictions between the present and the past, between different epochs of the past, between different socio-ideological groups in the present, between tendencies, schools, circles and so forth, all given a bodily form. These languages of heteroglossia intersect each other in a variety of ways, forming new socially typifying languages. It might even seem that the very word language loses all meaning in this process - for apparently there is no single plane on which all these languages might be juxtaposed to one another (p. 291).

Greek had a strong influence on English political imagination. Legends dealing with real people and events contain unreal elements conventionally related with myth: confrontations of mortals and gods, superhuman triumphs, magic and monsters. Bellingham (2002) argues that: "it is hardly surprising to find the poets glamorizing the Greek heroes as well as embroiling the facts with mythical stories of gods and monsters" (p. 6). The resulting breaking of the surviving myths was hastened by later poets who wanted to alter them, offering different endings or explanation for a character's behaviour. These changes might only seem for variety, but they were mainly utilized to reflect contemporary social outlooks. In fact, the poets used mythical structure of their poetry to express the social and political problems of the time.

Hellenism introduced an openness and an innovative liability to the Greek mythology that could be used as a kind of escape. Curran (1993) states that Keats' mythological poems particularly Endymion, Hyperion and his odes are among 
some major Romanic creative works that could communicate new outlooks through international popularity of translation. Keats' interest in Greek Mythology can express itself "as a nostalgic yearning to escape into another place and another age apparently more golden than the present and sometimes as a desire to make the lesson of past immediately relevant to the urgencies of contemporary life" (Curran, 1993, p. 150). Curran (1993) says that: "In this respect Keats is less detached from political controversy than he is usually taken to be" (p. 64). In fact, the Romantics, merely by being poets were destined to react in at least one aspect. They recognized that as writers their task was to spread the ideas and to change the minds. Then Curran (1993) maintains that:

The Romantic's faith in the power of imaginative vision to transform the world is the source of some of their greatest achievement. To it we owe among other poets ....the odes and fall of Hyperion of Keats..... to rely on vision transform the world untouched by reality (p. 71).

\section{DISCUSSION}

In Ode on a Grecian Urn the urn is a product of rediscovery of the art of Greek poetry. Keats' Romantic discovery of Greek mythology was vigorous and creative and often expressive of his main concerns. The retransformation of cultural powers that could be traced back to Greece comes up with an understanding of Greek accomplishment related to social specificity. Curran (1993) asserts that: "Keats internalized from his encounters with Greek art a sense of strength, power and authority that demanded imitation, but also experienced a sense of tension" (p. 164). In his view "The urn itself is a silent historian and the poet makes strenuous efforts to interpret its legend" (p. 153). Besides, Matthews (2005) considers Keats a poet greatly influenced by Greek mythology:

No ancient poet would have dreamed of writing thus. There would have been no indistinct shadowy warmth, no breath of surrounding beauty: his delineation would have been cold, distinct, chiselled like the urn itself. The use which such a poet as Keats makes of ancient mythology is exactly similar. He owes his fame to the inexplicable art with which he has breathed a soft tint over the marble forms of gods and goddesses, enhancing their beauty without impairing their chasteness (p. 216).

In Keats's view, human experiences art in both social and alienating way. On the one hand, since art discloses to us the image of what we all have in common, it lets us to explore in it our shared social affiliation. Such discovery unveils to us our basic equality that would help us to democratize human history. On the other hand, art is also essentially excluding the human history that Keats hopes to have the potential to shape. Sider (1998) believes that:

The men, women, gods, and lovers depicted on the urn exist far above all breathing human passion. They live in the slow time of the urn's great art, their stories spatialized and therefore emptied of the real time and change which define human life. A human community formed from art is, in this sense, a contradiction in terms, a society robbed of human reality (p. 162).

Moreover, the urn's origins exist, as Wu (1999) argues, in the cult-hymns of Ancient Greece and in the songs where Pindar, the great lyric poet of fifth-century Greece, celebrates triumphs in the ancient games. He notes that: "By definition, a hymn is an act of religious worship, while Pindar not only links ephemeral human deeds to what is enduring and divine, but also embodies social solidarity, because his songs, written for public performance, made him literally the voice of the community" (p. 239). Thus, it can be indicated that mytho-poetic patterns of thought coexist with modern forms while they are supporting each other. Therefore, Dialogical nature of realities outlined by Bakhtin's theories reveals that Keats' odes gives us resources we need to come to understand the social, political and ethical life of societies and the practical nature of trust within them.

Romantic period was involved in living through the exasperation of elevated ambitions in modern times. Keats's urn is expressive of both desire and frustration where images coexist in and out of existence. Curran (1993) believes Keats as the poet of oxymoron "who created for himself bowers of imagined pleasure in the midst of the wreckage of a wartorn world" (p.233). In truth, his ode springs from a continuous kind of experience that is an extreme consciousness of the pleasure and pain, the happiness and the grief of human life. This awareness is feeling and becomes also a thought that the poet sees them in others and feels them in himself. It is a sort of pondering of a lot of human beings, who want to fulfil their desire of happiness in a world where pain and pleasure are unavoidably connected to each other.

It seems necessary to be armed with a little knowledge of Greek mythology before starting any kind of review on Keats's Ode to a Nightingale. As mentioned by Abrams (1987) in The Norton Anthology of English Literature, Keats in his poetry attempted to hold a strong position within mythology of English poetry. Ode to a Nightingale begins when Keats admits feeling a drowsy numbness that he relates using drugs like hemlock or opium, or to drink from the classical river, Lethe, which causes humanity to forget what it was like to live a common life. It is obvious that the reason Keats was so interested in Greek mythology is due to the fact that the gods and spirits of Classical mythology barely displayed special qualities of natural world that Keats was willing to make common people apprehend it. The examples can be seen in Tasting of Flora and the country green, not charioted by Bacchus and his pards, the former as goddess of flower and the latter as goddess of wine that are mentioned by Abrams (1987). According to Keats's idea of salvation, the mythological figures and their relationships are emblem of the experiences that humans need to go through for developing their soul in spite of the suffering that it sometimes may cause. Thus, it is important to note that in human activities with dialogical nature, the workings of these divine elements are not something supernatural or external to the social activity. 
The basic story of Ode to Psyche is a popular myth. In the story told by the Roman author Apuleius in the $2^{\text {nd }}$ century, as mentioned by Abrams (1987), the youngest and the prettiest daughter of a king was Psyche. She was so charming and beautiful that Aphrodite, the goddess of love and beauty, became envious of her, sent her son, Eros, the god of love (the Cupid of Roman mythology and the winged boy of Keats's poem) in order to punish Psyche for being so gorgeous. But Eros became so surprised and absorbed by Psyche's beauty that he pierced himself with his own arrow and fell in love with her. Eros called for Psyche to his temple, but he kept to seem invisible to her, came to her only at night and ordered her not to try and want to see his face. One night, Psyche strived to light a lamp to have a glimpse at her lover; but breaking his trust by her made Eros so angry that he decided to leave her. Psyche was made to perform some laborious tasks to appease Venus and gain back Eros as her husband. Psyche is symbol of the soul in Greek mythology and the story can be seen as an allegory of the soul's expedition through life and finally, its unification with divine powers after being suffered by life's grieves and death. Therefore, as Sider (1998) believes, representation of Eros is not the statue of an ideal trans-historical society: "but Keats attempts to present it as the spring of potentially social power" (p. 12).

Psyche's tale and her experiences with Cupid are mythical expression of the idea of vale of soul making. This concept was first revealed in a letter of May 1819 in which Keats rejected the Christian belief that the earth is a vale of tears to turn it as a vale of soul making. It claims that the soul becomes matured through suffering and love in order to achieve a higher understanding of the stability of good and evil which is the crucial bond in human experience between pleasure and pain. Indeed, when Keats composed this poem, his mind was busy with the soul that is grown through suffering. It is Keats's particular quality of his thought when he ties soul's development (a positive experience) to suffering (a negative experience). The troubled nature of life and the attempt to connect opposites exist through his poetry.

Although it is believed that the gods lack their power in modern communities, Keats's Ode to Psyche still wishes for transcendence that means to go beyond the limits of real life to obtain a higher reality which can involve the greater capabilities like spirit and fancy. The narrator, revitalized by young goddess, becomes her idolizer. His imagination leads him to communicate with both Psyche's natural and supernatural aspects, and kind of his glorification is within himself when Ode to Psyche functions as a song in reverence of the goddess. The narrator remains the prophet for Psyche and says in the final stanza:

Yes, I will be thy priest, and build a fane

In some untrodden region of my mind,

Where branched thoughts, new grown with pleasant pain,

Instead of pines shall murmur in the wind. (Abrams, 1987, p. 1844)

Therefore, in this ode, Keats tries to lead the reader's consideration toward the internal link with other features of human life and can also form reader's reaction to it by the use of Psyche's image that appears to be dialogically shared between the poet and reader.

Briefly, in this ode, Keats's narrator addresses the goddess, Psyche, forcing her to listen to his words, and wanting her to forgive him for singing to her own secrets:

$O$ Goddess! Hear these tuneless numbers, wrung

By sweet enforcement and remembrance dear,

And pardon that thy secrets should be sung. (Abrams, 1987, p. 1843)

In the second stanza, the speaker addresses Psyche again, portray her as the most elegant and the youngest of all the Olympian gods and goddesses: O latest born and loveliest vision far, of all Olympus' faded hierarchy. He assumes that, unlike other divine powers, Psyche does not own any trapping place of worship: She has no temples, no altars, and no choir to sing for her etc. But the speaker is willing to say that even in the conflicted days of his own time that divinities' power is fallen, he would like to worship Psyche and become her choir:

So let me be thy choir, and make a moan

Upon the midnight hours;

Thy voice, thy lute, thy pipe, thy incense sweet. (Abrams, 1987, p. 1844)

Thus, Keats's energetic intonation in praising Psyche and becoming her priest clearly registers the other's presence that creates a kind of portrait in sound the addressee to whom he is speaking.

The three stanzas of the Ode on Melancholy discusses about the subject of how to cope with sufferings and pain. The first stanza suggests what not to do: The sufferer should not go to Lethe, or forget their sadness (Lethe is the river of forgetfulness in Greek mythology); should not commit suicide (nightshade, the ruby grape of Prosperpine, is a poison; Prosperpine is the mythological queen of the underworld as mentioned in the Anthology); and should not become infatuated with symbols of misery, grief and death the beetle, the death-moth, and the owl. Because, as the speaker contends, it will make the agony of the spirit drowsy, and the sufferer should do his best to stay conscious of his deepest anguish and suffering.

In the third stanza, Keats argues that pain and pleasure are closely related and affected: Beauty is doomed to die, joy is short-lived, and the flower of joy is turning to poison while the bee-mouth sips for good. The narrator states that the shrine of melancholy is in the temple of Delight, but that it will only be possible to be visible if you can overcome yourself with pleasure until it shows its heart of sadness, by burst Joy's grape against his palate fine. The one who can 
do this should taste the sadness of melancholy's power and be among her cloudy trophies hung. In his ode, the poem's creator in dialogical way is encouraging the reader to react against the Melancholy and he tells what is advisable to do and what is not. Moreover, this poem goes through the nature of melancholy and recommends a treatment for it: to defeat the fit of melancholy, human has to be entirely involved at the top of an emotional position, which makes the sensitivity sharper to pleasure or even to pain.

\section{CONCLUSION}

To conclude, it can be said that Keats, like many other Romantic poets, was greatly influenced by Greek mythology and made an attempt to deploy mythological symbols and characters to communicate his experiences with his reader. Since mythological concepts were mostly rooted in social and political events, Keats took this implication into account in order to reflect sufferings of his troubled society. On the other hand, mythological air of his poetry can be seen as an escape into the imaginary world of legends from the harsh and conflicted world of reality. Thus, these mythological images are a kind of a shared sense that affords the readers and the poet the possibility of coordinating their thoughts together in term of a shared reflection that can be expressed in response to the current conditions. This common sense can be found in dialogical nature of social attitudes of Keats's poetry that invokes reactions and responses from the individuals in society that are parts of uniquely created joint responses to joint circumstances.

\section{REFERENCES}

[1] Abrams, M. H. (1987). The Norton anthology of English literature: The major authors. New York: William Warder Norton \& Company.

[2] Bellingham, D. (2002). An Introduction to Greek mythology. Boston: Chartwell Books.

[3] Curran, S. (1993). The Cambridge companion to British romanticism. New York: Cambridge University.

[4] Dentith, S. (1995). Bakhtinian thought. London: Routledge.

[5] Hashemi, S. \& Kazemian, B. (2014a). Dialogical nature of structure in Keats's odes as a circular escape from pain to pleasure: A Bakhtinian perspective. International Journal of Linguistics and Literature, 3(2), 63-74. Retrieved from: http://www.iaset.us/view_archives.php?year=2014_14_2\&id=65\&jtype=2\&page=1 (20/4/2014).

[6] Hashemi, S. \& Kazemian, B. (2014b). A Bakhtinian dialogical nature of theme in Keats's odes as a circular escape from pain to pleasure. International Journal of Language and Literature, 2(2), in press.

[7] Holquist. M. (1981). The dialogical imagination: Four essays. Austin: University of Texas Press.

[8] Holquist, M. (2002). Dialogism: Bakhtin and his world. London/ New York: Routledge.

[9] Matthews. G. M. (2005). John Keats: The critical heritage. London/ New York: Routledge

[10] Sider, M. J. (1998). The dialogic Keats: Time and history in the major poems. Washington DC: Catholic University of America Press.

[11] Wu, D. (1999). A Companion to Romanticism. Boston: Wiley-Blackwell.

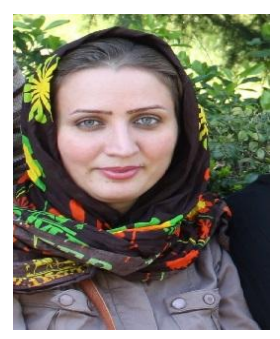

Somayyeh Hashemi is a PhD candidate and was born in Tabriz City, East Azerbaijan Province, Iran in 1984. She received her M.A. degree from Islamic Azad University-Tabriz branch, Iran in English Literature. Currently, she is a lecturer in Osveh University in Tabriz, Iran. Her major areas of interest are Bakhtinian studies, Systemic functional linguistics, Discourse Analysis, Rhetoric, Critical Discourse Analysis and Romanticism, Appraisal Framework, ELT and EFL. She has published several articles based on her areas of interests.

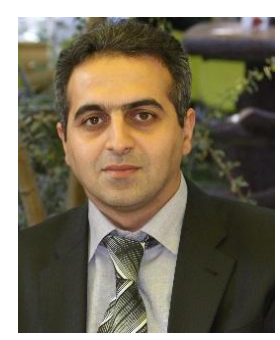

Bahram Kazemian is a PhD candidate and was born in Tabriz City, East Azerbaijan Province, Iran in 1980. He obtained his B.A. in English Translation and his M.A. in ELT from Islamic Azad University-Tabriz branch, Iran. Currently, he is the managing director of Unique Language Center in Tabriz. He has a ten-year experience in TEFL at different language institutes in Tabriz. His major areas of interest are Systemic Functional Linguistics, Critical Discourse Analysis, Rhetoric, Bakhtinian Studies, Contrastive Analysis, Discourse Analysis, Appraisal Framework, ELT and EFL. He has published several articles and one book based on his areas of interests. 